\title{
BMPR1A wt Allele
}

National Cancer Institute

\section{Source}

National Cancer Institute. BMPR1A wt Allele. NCI Thesaurus. Code C51727.

Human BMPR1A wild-type allele is located in the vicinity of $10 q 22.3$ and is approximately $169 \mathrm{~kb}$ in length. This allele, which encodes bone morphogenetic protein receptor type IA protein, is involved in signal transduction pertaining to bone morphogenesis. Germline mutations in the gene cause a subset of juvenile polyposis syndrome and Cowden syndrome. 